\author{
Andriej SZUTOW \\ Moskiewski Uniwersytet Państwowy im. M. Łomonosowa \\ polit_msu@bk.ru
}

\title{
SYSTEM WIELOPARTYJNY WE WSPÓŁCZESNEJ ROSJI: ETAPY POWSTAWANIA I ROZWOJU
}

ABSTRACT Multiparty system in contemporary Russia: stages of formation and development

Multiparty system exists in Russia for a bit more than 20 years. Within different political science discussions, the questions of functioning of multiparty system, organization of the party structure, positioning of parties in the society and state, politico-ideological identity of parties, creation of stable electoral base, cross-party coalitions, formation of party elites as a factor of party systems' sustainability, etc. were considered. Solving of these problems is impossible without learning of historical experience of multiparty system development in contemporary Russia. According to the analysis of party functioning, it is supposed to emphasize five stages of multiparty system development: „political pluralism” (end of 1980's - beginning of 1990's), „chaotic multiparty system” (beginning of 1990's), attempt to form a multiparty system (1995-1999), and development of the „political party state” (2000-2010) and democratization of party construction (from 2011). Within these stages current questions of political system functioning were being solved, that allowed creating of large political parties with comparatively stable electoral base, significant organizational and financial resources. On the agenda of the last stage is a request for the empowerment of specific social groups, development of new party organizations and further perfection of Russian political system.

Keywords: multiparty system, political system, political history

Słowa kluczowe: system wielopartyjny, system polityczny, historia polityczna 
Tatus i przyszłość partii we współczesnych systemach politycznych od czasu do cza-

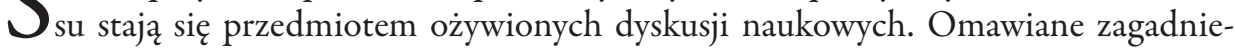
nie jest wieloaspektowe: od kwestii struktury, funkcjonowania, pozycjonowania partii w społeczeństwie i państwie do granic i warunków istnienia partii jako instytucji politycznych w globalnej społeczności. We współczesnej Rosji, gdzie system wielopartyjny liczy zaledwie dwie dekady, tematyka tego rodzaju dyskusji jest bardziej zróżnicowana - zostaje uzupełniona o kwestie polityczno-ideologicznej tożsamości partii, stworzenia stabilnego elektoratu, koalicji międzypartyjnych, kształtowania się elit partyjnych jako czynnika stabilizującego systemy partyjne etc. Kwestii tych, co zrozumiałe, nie można optymalnie rozwiązać bez kompleksowej analizy przebytej drogi i historycznego doświadczenia tworzenia systemu wielopartyjnego we współczesnej Rosji, jakkolwiek dosyć krótkiego w porównaniu z innymi krajami.

Jedną z wyraźnych tendencji procesu politycznego ubiegłego stulecia była rosnąca rola partii politycznych w życiu społeczeństw. Wiek potęgi organizacji partyjnych zrodził zjawiska systemów jednopartyjnych, dwupartyjnych, wielopartyjnych, które do dnia dzisiejszego w decydujący sposób wpływają na systemy polityczne państw. Występując w roli pośrednika w relacjach między społeczeństwem i władzą państwową, organizacje partyjne „absorbują” aktywność polityczną szerokich warstw społecznych, nadając jej instytucjonalny charakter. Dzięki temu osiągana jest koordynacja interesów różnych grup społecznych, zagwarantowane zostaje sprzężenie zwrotne w ramach układu politycznego, wzmacniana jest stabilność jego funkcjonowania i legitymizacja systemu politycznego.

Badania rozwoju partii politycznych i systemów partyjnych nie można oddzielić od analizy transformacji systemu wyborczego. Te fundamentalne komponenty procesu politycznego powinny być rozpatrywane łącznie, traktowane jako podstawa funkcjonowania systemu politycznego i zachodzących w nim zmian. Ważne jest przy tym uwzględnianie zarówno aspektów formalnych i prawnych, jak również praktyk nieformalnych. Rozwój systemu partii politycznych w dużej mierze zależy od struktury społecznej i kultury politycznej danego społeczeństwa. Skomplikowana sieć instytucji formalnych i nieformalnych kształtuje mechanizmy systemu partyjno-politycznego, wypełnia go dynamiką realnego życia politycznego.

Instytucja wielopartyjności odzwierciedla wysoki stopień fragmentacji współczesnych społeczeństw, odznaczających się złożonością struktury społecznej i konfiguracją interesów różnych grup społecznych. $Z$ tego powodu jest ona optymalnym i skutecznym wskaźnikiem orientacji wartościujących, zamiarów i preferencji aktywnych politycznie obywateli, którzy dostrzegają w partiach wygodny i bezpośredni kanał dla komunikowania swoich stanowisk centrom decyzyjnym. Taka charakterystyka systemu wielopartyjnego jest na ogół prawdziwa w przypadku społeczeństw o stabilnym systemie politycznym. Natomiast w krajach, które dopiero rozpoczęły radykalne przeksztalcenia instytucji politycznych, pojawiające się partie i protopartie otoczone są licznymi ogniwami pośredniczącymi w formie organizacji społecznych, korporacji zawodowych, struktur lobbingu etc. Te ostatnie bezpośrednio konkurują z partiami politycznymi 
o dostęp do procesu podejmowania decyzji. Pierwszy etap konstytuowania się systemu wielopartyjnego charakteryzuje się obecnością i zaangażowaniem politycznym ugrupowań, które w stabilnych społeczeństwach, z reguły, nie mają ambicji politycznych.

W Rosji na przełomie lat 80. i 90. XX w. kształtowaniu się systemu wielopartyjnego towarzyszyły głębokie przemiany, które objęły bez wyjątku wszystkie sfery życia społecznego. Źródeł zarówno współczesnego systemu wielopartyjnego w Rosji, jak również pierwszego okresu jego kształtowania się, które zostało zahamowane na ponad 100 lat, należy upatrywać w systemowym kryzysie zarządzania społeczeństwem. W obu przypadkach kryzys w znacznym stopniu był skutkiem potężnych procesów rozwoju politycznego, który stał się udziałem społeczeństwa rosyjskiego. Cechą charakterystyczną naszego społeczeństwa był fakt, że procesy te wyprzedzały kształtowanie się nowych instytucji politycznych, zdolnych do nadania zwiększonej aktywności politycznej $\mathrm{w}$ formach konstruktywnych, co pozwoliłoby tym samym bardziej efektywnie zarządzać systemem społecznym. Wyjściem z kryzysu z początku XX w. było wprowadzenie systemu jednopartyjnego, w którym zarządzanie powstałym Związkiem Radzieckim realizowane było przez partię komunistyczną. Rozwiązanie sprzeczności radzieckiego systemu politycznego pod koniec lat 80 . i na początku lat 90 . XX w. doprowadziło do tego, że kraj wszedł na drogę rozwoju systemu wielopartyjnego (ze wszystkimi skutkami ubocznymi i błędami tego procesu).

W trakcie tworzenia współczesnego rosyjskiego systemu wielopartyjnego można wyodrębnić kilka podstawowych etapów, z których każdy jest związany z odpowiednimi cyklami wyborczymi i odznacza się pewnymi zmianami w układzie sił politycznych oraz pozycjonowaniu partii i systemów partyjnych. Pierwszy z tych etapów to formowanie się pluralizmu politycznego w ZSRR.

\section{PIERWSZY ETAP. „PLURALIZM POLITYCZNY”W ZSRR NA PRZEŁOMIE LAT 80. I 90. XX W.}

Przesłanki rozwoju pluralizmu w ZSRR kształtowały się przez kilka dziesiątków lat, od początku lat 60 . XX w. w miarę socjalnego różnicowania się społecznego radzieckiego społeczeństwa i pojawienia się nowych, niejawnych grup interesów. Wkrótce po dojściu do władzy Michaiła Gorbaczowa została ogłoszona polityka pierestrojki, która stanowiła odpowiedź na widoczne zmiany w życiu społeczeństwa. Obrano kurs strategiczny na „kompleksową i rewolucyjną odnowę społeczeństwa radzieckiego”, wkrótce reformy sięgnęły samych podstaw systemu politycznego. Ważną cezurą historyczną była XIX Wszechzwiązkowa Konferencja KPZR, zwołana w 1988 r., w czasie której podjęto decyzję o zorganizowaniu wyborów i przeprowadzeniu I Zjazdu Deputowanych Ludowych ZSRR.

W tym samym roku na Nadzwyczajnej XII Sesji Rady Najwyższej ZSRR przyjęto ustawy „O zmianach i uzupełnieniach Konstytucji (Ustawy Zasadniczej) ZSRR” („Об изменениях и дополнениях Конституции [Основного Закона] СССР”) i „O wyborach Deputowanych Ludowych ZSRR” („О выборах народных депутатов 
CCCP”). Te akty normatywne zmieniły organizację władzy państwowej w Związku Radzieckim. Władzą najwyższą był Zjazd Deputowanych Ludowych ZSRR, ze składu którego uformowała się Rada Najwyższa ZSRR - stały organ, spełniający funkcję ustawodawczą i nadzorczą. Istotne zmiany wprowadzono także w radzieckim systemie wyborczym - prawnie została zagwarantowana zasada alternatywności w wyborach deputowanych ludowych, umożliwiająca kilku kandydatom ubieganie się o mandat. Przewidywano także bezpośrednią reprezentację organizacji publicznych, które przeszły rejestrację państwową, wśród których, poza KPZR był Komunistyczny Związek Młodzieży (Komsomoł), Związek Dziennikarzy, Akademia Nauk ZSRR i inne.

Wybory deputatów ludowych odbyły się wiosną 1989 r. Już na I Zjeździe ukształtowała się legalna opozycja wobec ówczesnej władzy. Wielu deputowanych, którzy nie zgadzali się z kursem politycznym, zjednoczyło się w Międzyregionalną Grupę Deputowanych. Znanymi jej członkami byli: akademik Andriej Sacharow, profesor Leningradzkiego Uniwersytetu Państwowego Anatolij Sobczak, ekonomista Gawriił Popow i Borys Jelcyn. Wystąpili oni z żądaniami przyspieszenia reform politycznych, nalegając na zniesienie szóstego artykułu Konstytucji ZSRR o kierowniczej roli KPZR.

Zjazd Deputowanych Ludowych ZSRR, zapewniając szeroką reprezentację różnych warstw społeczeństwa, stał się forum dla szerokiej dyskusji, miejscem, gdzie zderzały się różne interesy i poglądy na temat rozwoju kraju. Rozwój zasady pluralizmu w procesie politycznym odbywał się w kontekście stale pogłębiającego się kryzysu gospodarczego. Zaostrzenie walki politycznej nie sprzyjało wypracowaniu trwałych zasad zarządzania w sytuacji kryzysowej. Spadkowi gospodarczemu towarzyszyła głęboka stagnacja polityczna i ideologiczna. Kierownictwo państwa nie było w stanie wytyczyć strategicznego kursu rozwoju kraju i ochronić go przed kryzysem, który ogarnął wszystkie sfery życia społecznego.

W 1990 roku decyzją Rady Najwyższej ZSRR został zniesiony szósty artykuł Konstytucji ZSRR o kierowniczej roli KPZR, co ostatecznie utorowało drogę rozwoju systemu wielopartyjnego w Związku Radzieckim. Zniesienie monopolu politycznego KPZR, która jednoczyła Związek Radziecki, osłabiło jednak konstrukcje nośne systemu politycznego kraju. Konflikt organów władzy związku i republik szybko przerodził się w konflikt legislacyjny. Sprzeczności częściowo zostały rozwiązane w 1991 r., po tzw. „paradzie suwerenności” - serii oświadczeń republik narodowych o wyjściu ze składu ZSRR. Kryzys sierpniowy wielokrotnie wzmocnił tendencje odśrodkowe, przyspieszył upadek radzieckiego systemu politycznego: 26 grudnia 1991 r. Związek Radziecki przestał istnieć.

Ten etap wyodrębniania się i uobecniania alternatywnego (obok oficjalnego) politycznego punktu widzenia na przekształcenia w Związku Radzieckim charakteryzował się masowym i żywiołowym kształtowaniem elit opozycyjnych. Na miejscu opozycyjnie nastawionych intelektualistów i kręgów dysydenckich pojawiła się siła dość potężna, wpływowa politycznie, choć słabo zorganizowana. Był to konglomerat ruchów, ugrupowań i innych instytucji rodzącego się społeczeństwa obywatelskiego, połączonych sprzeciwem wobec radzieckiej nomenklatury partyjnej, dysponującej na tym etapie instytucjami władzy partyjnej. 


\section{DRUGI ETAP. „CHAOTYCZNA WIELOPARTYJNOŚĆ” W ROSJI NA POCZĄTKU LAT 90. XX W.}

Wraz z upadkiem Związku Radzieckiego na arenę walki politycznej w Rosji wstąpiło wiele ugrupowań partyjnych. Ramy prawne procesu wyborczego dopiero się tworzyły. Władza państwowa, w istocie, przestrzegała linii ustanawiania pluralizmu politycznego przy minimalnej regulacji prawnej procesu wyborów. Na początku lat 90. prawie wszystkie ugrupowania wyborcze były protopartiami - stosunkowo nielicznymi, bez wyraźnego zaplecza elektoratu i spójnego programu ideowego. Wyjątkiem była Komunistyczna Partia Federacji Rosyjskiej (KPFR), która po rozwiązaniu KPZR i zawieszeniu działalności Komunistycznej Partii Rosyjskiej Federacyjnej Socjalistycznej Republiki Radzieckiej w sierpniu 1991 r., zdołała zachować swój aktyw partyjny. Na podstawie decyzji Trybunału Konstytucyjnego Federacji Rosyjskiej z 1992 r., który uznał konstytucyjność podstawowych organizacji terytorialnych KPZR i ich prawo do organizowania się w partię polityczną ${ }^{1}$, Partia Komunistyczna dość szybko odtworzyła swoje struktury organizacyjne. W 1993 r. ostatecznie zakończyło się kształtowanie Komunistycznej Partii Federacji Rosyjskiej (KPFR) pod kierownictwem Giennadija Ziuganowa poprzez połączenie rozproszonych regionalnych oddziałów KPZR. W owym czasie była to jedyna partia mogąca konkurować z kręgami władzy, dysponująca stosunkowo wyrazistym programem politycznym i możliwościami organizacyjnymi. Równolegle z tworzeniem KPFR pojawily się i inne partie o orientacji lewicowej i radykalnym nastawieniu, które były raczej protopartiami i nie wytrzymały konkurencji w walce o wyborców.

Liberalne skrzydło sceny politycznej formowało się głównie wokół przedstawicieli byłej nomenklatury partyjnej, intelektualistów, rodzącej się elity biznesu. Wokół swojego lidera gromadziła się także Liberalno-Demokratyczna Partia Rosji, oczekując startu w najbliższych wyborach.

Już przed wyborami do Dumy Państwowej w 1993 r. w Rosji, można było zauważyć wiele antagonistycznych organizacji politycznych, które stanowiły różnorodną i niespójną kompozycję rozmaitych ugrupowań, kierowanych przez znanych lub „wykreowanych" w mediach liderów, nieprezentujących wyrazistej platformy polityczno-ideologicznej. Wyjątek stanowily jedynie blok liberalny i KPFR, które miały własny pogląd na kierunek rozwoju społeczno-politycznego i gospodarczego państwa.

Wybory do Dumy Państwowej w 1993 r. były organizowane zgodnie z Ordynacją „O wyborach deputowanych do Dumy Państwowej” (Положение „О выборах депутатов Государственной Аумы”) ustanowioną dekretem Prezydenta Rosji. Wybory zostały przeprowadzone na podstawie mieszanego systemu wyborczego: połowa deputowanych wybierana była z list partyjnych (system proporcjonalny), a druga połowa w okręgach jednomandatowych (system większościowy). Minimalny „próg” wyborczy

Dokładniej por. Ф. М. Рудинский, „Дело КПСС” в Конститущионном Суде, Москва 1999, s. $402-431$. 
uprawniający daną siłę polityczną do uczestnictwa w podziale mandatów został ustanowiony na poziomie $5 \%$ ogólnej liczby głosów. Partie mogły startować w wyborach samodzielnie lub jako część zjednoczenia wyborczego bądź bloku. Zarejestrowano 13 federalnych list zjednoczeń wyborczych. Ośmiu zjednoczeniom udało się przekroczyć próg 5\% i uzyskać prawo uczestnictwa w podziale mandatów na szczeblu federalnym.

W Dumie Państwowej Federacji Rosyjskiej pierwszej kadencji, która zgodnie z Konstytucją miała urzędować, w drodze wyjątku, tylko dwa lata ${ }^{2}$, nie było partii, które zdobyłyby większość konstytucyjną, ani stabilnych koalicji. Ogólnie rzecz biorąc, kształtujący się w kraju system „skrajnej wielopartyjności” (jak go nazywali komentatorzy polityczni tego okresu) charakteryzował się znaczną niestabilnością. Duża dynamika systemu partyjno-politycznego była pochodną nie tylko liberalnego charakteru legislacji dotyczącej systemu partyjnego i prawa wyborczego, ale również - ogólnej ułomności normatywnej bazy prawnej (a nierzadko - po prostu braku odpowiednich norm prawnych). W nie mniej istotnym stopniu niestabilność była konsekwencją transformacji struktury społecznej, uniemożliwiającej kształtowanie się „żelaznych” elektoratów partii. Jedynymi partiami, które powstały na przełomie lat 80. i 90. XX w. i zachowały jedność oraz platformę ideologiczną do następnej dekady były Komunistyczna Partia Federacji Rosyjskiej (KPFR) i częściowo Liberalno-Demokratyczna Partia Rosji (LDPR).

Ten etap budowy systemu partyjnego odznacza się pierwszymi, bardzo nieśmiałymi próbami politycznego samookreślenia grup interesów, które doszły do głosu na przełomie lat 80. i 90. w warunkach liberalnego prawa dotyczącego partii i prawa wyborczego. Elity starały się stworzyć struktury organizacyjne i wylansować liderów, którzy byliby w stanie konkurować z powstającą "partią władzy” - grupą polityczną z otoczenia prezydenta Rosji Borysa Jelcyna, która uczyła się wykorzystywania „zasobów administracyjnych" w procesie politycznym. Ten problem został częściowo rozwiązany przez partie KPFR i LDPR.

\section{ETAP TRZECI. PRÓBA STWORZENIA SYSTEMU WIELOPARTYJNEGO (1995-1999)}

Okres budowy partii pomiędzy cyklami wyborczymi w latach 1993 i 1995 odznacza się się wzrostem nastrojów antyreformatorskich w społeczeństwie. Przeprowadzenie liberalnych reform przy nieustannie obniżającej się jakości życia nie satysfakcjonowało już kluczowych grup interesów w Rosji. To przyczyniło się do stopniowego wzmocnienia lewicowych nastrojów w społeczeństwie, które na arenie wyborczej reprezentowane były przede wszystkim przez KPFR, zdecydowanie poszerzającą bazę swojego poparcia społecznego.

2 Duma Państwowa Zgromadzenia Federalnego Federacji Rosyjskiej (Государственная Аума Федерального Собрания Российской Федерации) kolejnych kadencji była wybierana na okres 4 lat. W 2011 r. Duma Państwowa była wybrana na kadencję pięcioletnią, zgodnie z przyjętymi w 2009 r. poprawkami do Konstytucji Rosji. 
W tym kontekście w pełni zrozumiałe jest dążenie federalnych władz wykonawczych do stworzenia partii proprezydenckiej („partii władzy”), która mogłaby zapewnić silne wsparcie dla inicjatyw prezydenta w parlamencie. Pierwsza próba stworzenia organizacji tego typu została zrealizowana w postaci bloku wyborczego „Wybór Rosji” („Выбор России”) (1993), na czele którego stanął lider liberalnego skrzydła reformatorskiego Jegor Gajdar. Partia miała za zadanie zapewnienie wsparcia legislacyjnego dla liberalnych reform, wprowadzanych przez rząd. Jednak wkrótce po wyborach parlamentarnych w 1993 r. partia coraz częściej zaczęła krytykować program działań władzy wykonawczej i przeszła do tzw. „opozycji demokratycznej”.

Nową „partią władzy” miało stać się ugrupowanie społeczno-polityczne „Nasz Dom - Rosja” („Наш дом - Россия”), utworzone na polecenie prezydenta Rosji Borysa Jelcyna przez premiera Rosji Wiktora Czernomyrdina w 1995 r. Zrzeszenie to podjęło próbę opanowania centrum spektrum politycznego.

Nowa organizacja skupiała przedstawicieli postkomunistycznej nomenklatury administracyjno-gospodarczej, których jednoczyły nie tyle jednolite poglądy polityczne, lecz wspólne interesy. W szczególnych warunkach polityki postradzieckiej „Nasz Dom - Rosja” to specyficzna koalicja elit gospodarczych, reprezentujących kluczowe sektory rosyjskiego przemysłu: kompleks paliwowo-energetyczny, metalurgię oraz finansowo-biurokratyczny klan moskiewski. „Partia władzy”, jednocząca przede wszystkim przedstawicieli postkomunistycznej nomenklatury administracyjnej i gospodarczej, starała się przeciwstawić ideologicznym stanowiskom komunistów i liberałów pragmatyczny plan działań, odrzucający radykalne zmiany. Linia polityczna partii, w istotnych punktach odzwierciedlająca stanowisko federalnej władzy wykonawczej, znamionowała dążenie do osiągnięcia kompromisu między różnymi siłami politycznymi, stabilizacji i normalizacji sytuacji politycznej, dążenie do zapobieżenia gwałtownym zmianom społecznym i politycznym.

Taki był układ sił w systemie partii politycznych w Rosji w przededniu wyborów do Dumy Państwowej drugiej kadencji, które odbyły się 17 grudnia 1995 r., według ordynacji, którą przyjęto przed wyborami - Federalne Prawo „O wyborach deputowanych do Dumy Państwowej Zgromadzenia Federalnego Federacji Rosyjskiej” (Федеральный закон „О выборах депутатов Государственной Аумы Федерального Собрания Российской Федерации"). Wybory parlamentarne ponownie odbywały się na podstawie mieszanego systemu wyborczego: 225 mandatów było rozdzielanych z list partyjnych i 225 - w okręgach jednomandatowych. Ogółem, o miejsca w Dumie Państwowej ubiegały się 43 ugrupowania wyborcze. Po uwzględnieniu wyników wyborów, 39 organizacji partyjnych nie przekroczyło progu 5\%. Z list partyjnych do Dumy Państwowej weszły tylko cztery ugrupowania. Uwzględniając wyniki wyborów $\mathrm{w}$ jednomandatowych okręgach wyborczych, istotną przewagę przy rozdziale mandatów uzyskały siły lewicowe, reprezentowane przede wszystkim przez KPFR, która znacząco zwiększyła swoje wpływy w niższej izbie parlamentu.

Wyniki federalnego cyklu wyborczego w latach 1995-1996 z całą wyrazistością wyeksponowały problem formowania się koalicji parlamentarnych. Rozdrobnione ugrupowania partyjne nie były w stanie stworzyć większości konstytucyjnej, koniecznej dla 
przyjęcia przez izbę niższą kluczowych ustaw. Sytuację pogarszał fakt, że „partia władzy" nie była w stanie uzyskać pożądanej pozycji siły centrowej, która mogłaby zapewnić stabilność polityczną, zmniejszyć intensywność walk opozycji lewicowej i prawicowej. W tych okolicznościach zagrożona była legitymizacja całego ówczesnego systemu politycznego.

Przewidywalną reakcją sił politycznych w tej sytuacji były próby zawiązania trwałych koalicji. Jednoczenie się lewicowej opozycji odbywało się wokół KPFR. Po kampanii prezydenckiej Giennadija Ziuganowa KPFR stała się centralną organizacją lewicowej opozycji. Po prawej stronie sceny politycznej także dało się zauważyć tendencje do konsolidacji i integracji rozdrobnionych sił politycznych. Słaba i bez tego pozycja rządu niższej izby parlamentu ulega jeszcze większemu osłabieniu wobec planowanych procesów konsolidacji sił opozycyjnych. Centrum sceny politycznej, niejasno zarysowane, pozostawało nieobsadzone. Tak więc, ze względu na konieczność zapewnienia ogólnej stabilności systemu politycznego kluczowym wyzwaniem na najbliższe lata stało się stworzenie silnej centrowej partii prorządowej.

Proces polaryzacji sił politycznych, który trwał na przestrzeni kilku lat, osiągnął swego rodzaju kulminację w ramach cyklu wyborczego 1999 r. W tym okresie Duma Państwowa drugiej kadencji przeżywała kryzys, ponieważ wspomniane siły polityczne, aspirujące do reprezentowania politycznego centrum, prawie całkowicie straciły poparcie ze strony ludności. Szanse prorządowego ugrupowania „Nasz Dom - Rosja” na wejście do Dumy Państwowej trzeciej kadencji były niewielkie. W tej sytuacji Prezydent Rosji i jego otoczenie ponownie stanęli wobec zadania zorganizowania struktury politycznej, zdolnej połączyć znaczące ugrupowania wyborcze na płaszczyźnie ideologii centrowej.

Część elity politycznej utworzyła dwa nowe bloki - „Ojczyzna - Cała Rosja” („Отечество - Вся Россия”) і „Jedność” („ЕАинство”). Te duże ugrupowania wyborcze, stworzone w odstępie około miesiąca z inicjatywy przede wszystkim liczących się przedstawicieli biurokracji, oznaczają powstanie centrowej alternatywy dla lewego i prawego skrzydła systemu partyjnego.

Wybory do Dumy Państwowej Federacji Rosyjskiej trzeciej kadencji zostały przeprowadzone zgodnie z nowym Prawem Federalnym „O wyborach deputowanych do Dumy Państwowej Zgromadzenia Federalnego Federacji Rosyjskiej” (Федеральный закон „О выборах депутатов Государственной Аумы Федерального Собрания Российской Федерации") z 19 grudnia 1999 r. System wyborczy nie został znacząco zmieniony i zachował charakter mieszany. Należy tylko zaznaczyć, że zgodnie z przyjętym w 1997 r. Prawem Federalnym „O podstawowych gwarancjach praw wyborczych i prawa do udziału w referendum obywateli Federacji Rosyjskiej” (Федеральный закон „Об основных гарантиях избирательных прав и права на участие в референдуме граждан Российской Федерации") status ugrupowania wyborczego, uprawnionego do udziału w wyborach, mogła uzyskać tylko polityczna organizacja społeczna, mająca odpowiedni statut, a nie, jak dotychczas, każda organizacja społeczna. Ta innowacja świadczy o rozszerzeniu zakresu normatywnej regulacji stosunków wyborczych, która w nadchodzącej dekadzie uzyska nowy impuls. 
W wyborach w 1999 r. wzięło udział w sumie 26 organizacji wyborczych i bloków wyborczych, z których sześć weszło w skład Dumy Państwowej. Dość dobry wynik wyborczy ugrupowań „Ojczyzna - Cała Rosja” i „Jedność, a następnie ich zjednoczenie po wyborach w partię "Jedna Rosja” („ЕАиная Россия”) doprowadziło do powstania potężnej siły centrowej w Dumie Państwowej. Generalnie, na początku XXI w. można było obserwować w Rosji względną stabilizację systemu partyjnego, wyraźnie zarysowały się tendencje do umocnienia partii i ugruntowania pozycji centrowych w niższej izbie parlamentu. Było to w dużej mierze związane ze zmianą władzy prezydenckiej w kraju.

Na tym etapie rozwoju systemu partyjno-politycznego współczesnej Rosji wyraźnie zaznaczył się wektor ewolucji elity rządzącej w kierunku konsolidacji według modelu korporacyjnego. Oczywiste jest, że strukturyzacja elit według modelu korporacyjnego wcale nie oznacza, że „model partyjny” odszedł w przeszłość. Powstanie korporacji politycznych ujawniło raczej kryzys tożsamości społecznej i politycznej dotykający praktycznie wszystkich grup interesów w rosyjskim społeczeństwie, które jeszcze nie znalazły odpowiedniej reprezentacji w sferze politycznej. Ponadto była to odpowiedź na styl polityczny i improwizacje kierownictwa kraju w drugiej połowie lat 90., kiedy to wielu popularnych liderów, ze względów koniunkturalnych zostało zmuszonych do przejścia do opozycji.

\section{ETAP CZWARTY. BUDOWA „PAŃSTWA PARTYJNEGO” (2000-2010)}

Czwarty etap rozwoju współczesnego systemu partyjno-politycznego w Rosji wiąże się z nowym kursem władz federalnych na wzmocnienie instytucji politycznych i państwowych w latach 2000-2010. Był on realizowany w celu przezwyciężenia skutków radykalnych reform z poprzedniej dekady.

Groźba utraty jedności terytorialno-państwowej spowodowana niestabilnością polityczną kraju podyktowała konieczność zapewnienia jednolitej przestrzeni politycznej i prawnej w obrębie granic państwowych Rosji. Ogromne wyzwania, przed jakimi stała rosyjska państwowość, spowodowały gruntowną rewizję panującej liberalnej doktryny rządu, przyjętej na początku lat 90. Rząd federalny rozpoczął proces budowy „państwa partyjnego"3 którego podstawową składową powinny być silne i stabilne partie polityczne. W tym celu w połowie pierwszej dekady XXI w. została przeprowadzona zakrojona na szeroką skalę reforma systemu partyjnego i prawa wyborczego.

W 2001 r. zostało przyjęte Prawo Federalne „O partiach politycznych” (Федеральный закон „О политических партиях"). W istocie był to pierwszy normatywny akt prawny w Rosji, który ustanawiał jasne zasady stosunków między państwem i partiami politycznymi. Zgodnie z nową regulacją prawo do udziału w wyborach parla-

Pojęcie „państwa partyjnego” zostało wprowadzone przez niemieckich prawników i politologów w pierwszej połowie XX w. dla określenia systemu politycznego, w którym kluczowe decyzje w rządzeniu państwem podejmują partie polityczne jako główne podmioty systemu politycznego, które otrzymały wsparcie od swoich wyborców. 
mentarnych miały tylko partie polityczne i ich koalicje. Tworzenie ruchów wyborczych w przeddzień wyborów, tak popularne w latach 90., stało się odtąd niemożliwe. Ponadto, wraz z wejściem w życie ustawy, prawo do udziału w wyborach zostało przyznane tylko partiom politycznym, które mają status ogólnokrajowych, co zakłada istnienie oddziałów regionalnych partii w więcej niż połowie podmiotów Federacji. Tworzenie partii na zasadzie terytorialnej w myśl nowej ustawy również okazało się niemożliwe.

Zaostrzeniu uległy wymagania dotyczące minimalnej liczby członków partii politycznych. W $2001 \mathrm{r}$. minimalna liczba członków partii została ustalona na poziomie 10000 osób. Później liczba ta została zwiększona do 50000 osób, co istotnie utrudniało tworzenie i rejestrację ugrupowań społecznych jako partii politycznych.

Ważną zmianą w ordynacji wyborczej było uchwalenie w 2002 r. Prawa Federalnego „O podstawowych gwarancjach praw wyborczych i prawa do udziału w referendum obywateli Federacji Rosyjskiej” (Федеральный закон „Об основных гарантиях избирательных прав и права на участие в референдуме граждан Российской Федерации"). Zgodnie z tym aktem prawnym podczas wyborów do przedstawicielskich (ustawodawczych) organów władzy podmiotów Federacji co najmniej połowa deputowanych powinna być wybierana w systemie proporcjonalnym. Przed przyjęciem tej ustawy tylko w kilku podmiotach Federacji stosowano mieszany system większościowo-proporcjonalny, w większości regionów natomiast wybory do organów przedstawicielskich (ustawodawczych) odbywały się w okręgach jednomandatowych.

Wejście w życie tego prawa przyczyniło się do rozwoju działalności partyjnej na szczeblu regionalnym. W poprzedniej dekadzie wiele organizacji politycznych było „wirtualnymi” projektami o charakterze ogólnokrajowym, tworzonymi „pod” wybory do Dumy Państwowej. Wraz z przyjęciem nowej ustawy partie zostały włączone w proces rozwiązywania codziennych problemów rosyjskich regionów.

Wyniki federalnej kampanii wyborczej 2003 r. sprawiły, że „Jedna Rosja” stała się pierwszą partią polityczną o orientacji centrowej, której udało się zdobyć większość w izbie niższej parlamentu. Było to wyraźne świadectwo, że sytuacja polityczna w kraju ustabilizowała się, a obowiązujący system polityczny po raz pierwszy uzyskał legitymację obywateli.

Ostateczne umocnienie priorytetu uczestnictwa w walce politycznej dużych partii dokonało się w 2005 r. w związku z przyjęciem Prawa Federalnego „O wyborach deputowanych do Dumy Państwowej” (Федеральный закон „О выборах депутатов Государственной Аумы”). Zgodnie z tym aktem prawnym wybory deputowanych do niższej izby parlamentu miały opierać się na proporcjonalnym systemie wyborczym. W związku z tym wybory do niższej izby parlamentu w 2007 r. odbywały się już w systemie proporcjonalnym. W tym samym roku weszły w życie kolejne zmiany ordynacji wyborczej, które zwiększały próg wyborczy w wyborach do Dumy Państwowej do $7 \%$.

System proporcjonalny, w większości przypadków sprzyjający wzmocnieniu komponentu partyjnego w procesie politycznym, obowiązywał w wyborach federalnych i regionalnych. Partie stały się aktywnymi uczestnikami polityki regionalnej. Zostały 
zmuszone do przejścia od „wirtualnych” kampanii wyborczych do aktywnych działań praktycznych w terenie. Równocześnie partie o zasięgu ogólnokrajowym zapewniały konsolidację federalnych i regionalnych szczebli władzy państwowej. To był ważny krok w kierunku stworzenia jednolitej przestrzeni politycznej i prawnej na terytorium całego kraju. Wybory regionalne były swoistym wskaźnikiem poparcia dla programów politycznych, podstawowych modeli i strategii rozwoju państwa, proponowanych przez duże partie.

Bez wątpienia odnowiony system partyjno-polityczny nie był pozbawiony ułomności. Rygorystyczne wymagania odcinały drogę dużej liczbie konkurentów wyborczych. Nowa konfiguracja instytucjonalna charakteryzowała się ograniczoną zdolnością do adaptacji i ograniczoną wrażliwością na interesy i nastroje znacznych grup wyborców. Ogólna dynamika konkurencji między partiami spadła, osłabła motywacja do zmian kadrowych i doskonalenia metod pracy partyjnej.

Brak zaufania do partii jako instytucji politycznej w Rosji był szczególnie widoczny na poziomie regionalnym. Wprowadzenie nowego systemu wyborczego doprowadziło do spadku autorytetu regionalnych zgromadzeń ustawodawczych w oczach wyborców, zawęziło zakres konkurencji politycznej.

Ważną konsekwencją przeprowadzonej reformy było rozprzestrzenianie się praktyki tak zwanych „lokomotyw” wyborczych, gdy pierwsze miejsca list partyjnych zajmowali liderzy, którzy nie zamierzali być deputowanymi. W rezultacie mandaty otrzymywali ludzie, którzy nierzadko nie pracowali bezpośrednio z wyborcami, nie mieli doświadczenie w publicznej działalności politycznej i podejmowaniu decyzji.

Generalnie, reformy legislacyjne w zakresie budowy systemu partyjnego i systemu wyborczego utrudniły udział w wyborach ugrupowaniom społecznym. Możliwość konkurencji wyborczej miały teraz tylko duże, dobrze zorganizowane organizacje, prowadzące aktywną działalność partyjną na poziomie federalnym i regionalnym, w tym także w okresach między wyborami. Należy zauważyć, że nowa procedura wyborcza korespondowała z nastrojem ogólnego „zmęczenia” obywateli chaotyczną konkurencją polityczną lat 90 .

Zakrojony na szeroką skalę proces konsolidacji partii, czemu sprzyjała odnowiona w połowie pierwszej dekady XXI w. architektura instytucjonalna, istotnie przyczynił się do normalizacji funkcjonowania systemu politycznego. System wielopartyjny w Rosji przeszedł od rozwoju ilościowego do zmian jakościowych. Tworzenie partii przestało być czysto koniunkturalnym procesem, służącym tylko wąskim interesom korporacyjnym. Zwiększenie liczby członków partii doprowadziło do względnej stabilizacji konkurencji między nimi, pobudziło nawiązanie konstruktywnej współpracy między organami władzy wykonawczej i ustawodawczej.

Dla elit rządzących był to okres kontynuacji konsolidacji według zasad korporacyjnych. $Z$ większą konsekwencją stosowano hierarchiczną zasadę tworzenia elit. Równolegle kształtowała się tożsamość partyjna, zakładająca dyscyplinę i odpowiedzialność wobec lidera. Należy zauważyć, że imperatyw tożsamości partyjnej, praktycznie obcy (z wyjątkiem KPFR) organizacjom politycznym w latach 90., doprowadził do znacznego przegrupowania elit partyjnych i to na całej scenie politycznej. 


\section{ETAP PIĄTY. DEMOKRATYZACJA SYSTEMU TWORZENIA PARTII (OD 2011 R.)}

Konsolidacja systemu partyjnego i budowa „państwa partyjnego” była odpowiedzią na zagrożenia „skrajnej wielopartyjności”, obarczone ryzykiem rozpadu systemu politycznego. Jednocześnie system partyjny powstały pod koniec pierwszej dekady XXI w. nie był ukształtowany ostatecznie. Już w 2010 r. został obrany kurs na liberalizację legislacji dotyczącej systemu partyjnego i ordynacji wyborczej. Zaczęto stopniowo zmniejszać pułap wyborczy minimalnej liczby członków partii politycznej, minimalnej liczby regionalnych oddziałów etc.

Poprawki legislacyjne odzwierciedlały zmiany sfery społeczno-politycznej w społeczeństwie rosyjskim. Nowe kierunki przemian społecznych, wyznaczane przez nowoczesne technologie informacyjne, zmiany podstawowych wartości ekonomicznych globalnego świata bezpośrednio wpływają na tworzenie się struktur społecznych i zwiększenie ich zróżnicowania. Sprzyja to stopniowemu rozwojowi instytucji społeczeństwa obywatelskiego. Procesy te, charakterystyczne dla współczesnej cywilizacji, objęły także nasz kraj, a przede wszystkim pokolenia gospodarczo i społecznie aktywnych obywateli. Pod koniec pierwszej dekady XXI w. zarysowała się tendencja do zwiększenia aktywności obywatelskiej różnych grup społecznych, które nie znalazły reprezentacji własnych interesów politycznych w ramach reprezentowanych w parlamencie partii „systemowych”. Równolegle następuje rozwój środków komunikacji masowej. "Jądro" informacyjnej przestrzeni, które w latach 90. i w pierwszej dekadzie XXI w. kształtowały centralne kanały telewizyjne, rozmywa się za sprawą rozwoju środków komunikacji internetowej. Nowe realia społeczne stawiają nowe wyzwania wobec systemu politycznego.

Jednym z rezultatów nawarstwiających się zmian było znaczące upolitycznienie aktywności obywatelskiej na szeroką skalę w ramach federalnego cyklu wyborczego w latach 2011-2012. Zwiększona aktywność polityczna ujawniała się w formach pozainstytucjonalnych. Pilnym zadaniem stało się skorygowanie schematu instytucjonalnego w celu stabilizacji systemu politycznego, przy zachowaniu jego funkcjonalności.

W 2012 r. wszedł w życie szereg istotnych poprawek do ustaw regulujących funkcjonowanie partii. Między innymi nowa redakcja Prawa Federalnego „O partiach politycznych” zakłada obniżenie minimalnej liczby członków partii z 40000 do 500 osób. Wymagania dotyczące minimalnej liczby członków w regionalnych oddziałach partii zostały zniesione. Następuje liberalizacja procedury rejestracji państwowej partii politycznej, zgodnie z którą jest możliwość poprawienia błędów stwierdzonych przez Ministerstwo Sprawiedliwości FR w dokumentach rejestracyjnych w okresie trzech miesięcy.

Znaczące zmiany w ordynacji wyborczej dotyczą liczby podpisów, wymaganych do udziału w wyborach. Partie polityczne zostały zwolnione z obowiązku zbierania podpisów wyborców przed każdymi wyborami. Jedynym wyjątkiem pozostały wybory Prezydenta Rosji. Nowa redakcja Prawa Federalnego „O wyborach Prezydenta 
Federacji Rosyjskiej” (Федеральный закон „О выборах Президента Российской Федерации") ustala wymóg zebrania co najmniej 300 tys. podpisów wyborców (poprzednio - nie mniej niż 2 mln podpisów) dla kandydatów startujących z wolnej stopy. Kandydat wysuwany przez partię polityczną, jest zobowiązany do zebrania co najmniej 100 tys. podpisów, zamiast $2 \mathrm{mln}$. Wyjątkiem są partie niereprezentowane ani w niższej izbie parlamentu, ani w ustawodawczych (przedstawicielskich) organach władzy państwowej przynajmniej jednej trzeciej podmiotów Federacji Rosyjskiej.

Znacznie obniżono próg udziału partii w kampanii wyborczej. Według danych na dzień 1 kwietnia 2015 r. w Rosji zarejestrowano 76 partii politycznych, a 73 mają prawo do udziału w wyborach ${ }^{4}$.

Pomimo konieczności liberalizacji ustaw regulujących funkcjonowanie partii i ordynacji wyborczej w Rosji w nowych warunkach, wprowadzono innowacje, które trudno uznać za celowe. Na przykład ustanowienie minimalnej liczby członków partii ogólnorosyjskiej na poziomie 500 osób oraz zniesienie minimalnego progu liczebności członków w oddziałach regionalnych. Zrozumiałe, że te zmiany nie dotkną partii „systemowych”. Nowo powstałe partie mogą jednak doświadczyć wielu trudności charakterystycznych dla okresu „chaotycznej wielopartyjności” lat 90. Dostęp do „wind politycznych” dla takich partii będzie bardzo utrudniony nie tylko ze względu na wyjściową nierówność szans w konkurencji z partiami „systemowymi”, ale także ze względu na małą zdolność do znalezienia własnej tożsamości polityczno-ideologicznej w konkurencji z kilkudziesięcioma, a nawet kilkoma setkami podobnych organizacji.

Należy zauważyć, że aktywny proces budowania struktur partyjnych odbywa się w dzisiejszej Rosji w warunkach istniejącego systemu partyjnego. W jego ramach uksztattowały się duże partie polityczne, które mają stosunkowo stabilny elektorat, znaczne zasoby organizacyjne i finansowe. $\mathrm{Z}$ drugiej strony większe zróżnicowanie struktury społecznej i zwiększenie aktywności obywatelskiej generują oczekiwanie rozszerzenia udziału politycznego określonych grup społecznych. To oczekiwanie nie mogło zostać zaspokojone w ramach ukształtowanej pod koniec pierwszej dekady XXI w. konfiguracji systemu polityczno-partyjnego. Wysoki „próg dostępu” do pola wyborczego generalnie oznaczał osłabienie legitymizacji systemu partyjnego w Rosji. Głównym wyzwaniem dla jego dzisiejszego rozwoju jest konieczność uwzględnienia „nowej aktywności politycznej", nadanie form instytucjonalnych pozainstytucjonalnej aktywności politycznej obywateli. W tym celu stworzono warunki polityczne i prawne dla budowania struktur partyjnych na dużą skalę. Przed nowymi partiami politycznymi będzie stało zadanie stworzenia zaplecza, wdrożenia mechanizmów organizacyjnych, zaproponowania programów, które będą konkurować w walce o poparcie rosyjskich

Политические партии в Российской Федерачии. 2015 год, wyd. 4, Москва 2015, s. 3. 
wyborców. Należy także uwzględniać możliwości doskonalenia systemu politycznego Rosji, elastycznego reagowania państwa na ewentualne korekty w przepisach regulujących sferę tworzenia partii.

Tłumaczenie: Magdalena Romanowska

\section{BIBLIOGRAFIA}

Политические партии в Российской Федерачии. 2015 год, wуd. 4, Москва 2015, s. 3.

Рудинский Ф. М., „Дело КПСС” в Конституционном Суде: Записки участника процесса, Москва 1999.

Andriej Juriewicz SZUTOW, doktor habilitowany nauk historycznych, profesor, dziekan Wydziału Politologii Moskiewskiego Uniwersytetu Państwowego im. M. Łomonosowa. 